\title{
EFISIENSI EKONOMI SISTEM TANAM LEGOWO PADI SAWAH STUDI KASUS DI KECAMATAN TOMOHON BARAT KOTA TOMOHON
}

\author{
Djuru Masrib Pandensolang \\ Vicky Ventje Johan Panelewen \\ Wenny Tilaar
}

\begin{tabular}{ll}
\hline Naskah diterima melalui Website Jurnal Ilmiah agrisosioekonomi@unsrat.ac.id & $:$ Minggu, 8 November 2019 \\
Disetujui diterbitkan & $:$ Kamis, 28 November 2019 \\
\hline
\end{tabular}

\begin{abstract}
This study aims to analyze how much profit is gained by applying the Legowo row planting system, analyzing the factors of production that affect rice production by applying the Legowo row planting system, analyzing whether the use of production factors allocated by farmers to the Legowo planting system economically already efficient. The study was conducted from January to April 2019 in Tomohon Barat Subdistrict, Tomohon City, North Sulawesi Province. The research location was chosen purposively with the consideration that West Tomohon Subdistrict was the center of rice production in Tomohon City with a total area of 447.40 ha of rice fields ( 52\% of the total area of rice fields in Tomohon City). The method used in this study is a survey method in the Kelurahan that has paddy fields in the West Tomohon District with interview techniques to respondent farmers. Determination of the sample is done by quota sampling method as many as 50 people taken from 7 (seven) villages in the District of West Tomohon by considering the area of land and the purpose of farming (commercial farm). The variables to be examined in this study are age, education, business experience, group membership, land area, seeds, fertilizer (Urea, SP36 and $N P K)$, labor (HKSP), production, and price. The results showed that the benefits of lowland rice farming with the application of the legowo planting system, farmers in Tomohon Barat Subdistrict, Tomohon City were not yet maximum and had not yet reached economic efficiency, production factors affecting rice production were land area, seeds, fertilizer (Urea, SP 36 and NPK Phonska) and labor, the use of production factors of land area, fertilizers (Urea, SP 36 and NPK Phonska) have not reached economic efficiency, the use of seed production factors and labor is inefficient. ${ }^{*}$ eprm*
\end{abstract}

Keywords: economic efficiency, jajar legowo, production factors, profits

\begin{abstract}
ABSTRAK
Penelitian ini bertujuan untuk menganalisa berapa besar keuntungan yang diperoleh dengan penerapan sistem tanam jajar legowo, menganalisis faktor-faktor produksi apa saja yang mempengaruhi produksi padi dengan penerapan sistem tanam jajar legowo, menganalisa apakah penggunaan faktor produksi yang di alokasikan petani dengan sistem tanam legowo secara ekonomi sudah efisien. Penelitian dilaksanakan dari bulan Januari sampai April 2019 di Kecamatan Tomohon Barat, Kota Tomohon, Provinsi Sulawesi Utara.. Lokasi penelitian dipilih secara sengaja (purposive) dengan pertimbangan Kecamatan Tomohon Barat merupakan sentra produksi beras di Kota Tomohon dengan total luas sawah 447,40 ha (52\% dari total luas sawah Kota Tomohon). Metode yang digunakkan dalam penelitian ini adalah metode survey di Kelurahan yang ada lahan sawah di Kecamatan Tomohon Barat dengan teknik wawancara kepada petani responden. Penentuan sampel dilakukan dengan metode quota sampling sebanyak 50 orang diambil dari 7 (tujuh) Kelurahan yang ada di Kecamatan Tomohon Barat dengan mempertimbangkan luas lahan dan tujuan usahatani (commercial farm). Variabel yang akan diteliti dalam penelitian ini adalah umur, pendidikan, pengalaman berusaha, keanggotaan dalam kelompok, luas lahan, benih, pupuk (Urea,SP36 dan NPK), tenaga kerja (HKSP), produksi, dan harga. Hasil penelitian menunjukkan bahwa keuntungan usahatani padi sawah dengan penerapan sistem tanam legowo,petani di Kecamatan Tomohon Barat Kota Tomohon belum maksimum dan belum mencapai efisiensi ekonomi, faktor produksi mempengaruhi produksi padi adalah luas lahan, benih, pupuk (Urea, SP 36 dan NPK Phonska) dan tenaga kerja, penggunaan faktor produksi luas lahan, pupuk (Urea, SP 36 dan NPK Phonska) belum mencapai efisiensi ekonomi, penggunaan faktor produksi benih dan tenaga kerja tidak efisien. ${ }^{*}$ eprm*
\end{abstract}

Kata kunci : efisiensi ekonomi, jajar legowo, faktor produksi, keuntungan. 


\section{PENDAHULUAN}

\section{Latar Belakang}

Padi (Oryza Sativa L.) telah menjadi bagian dari kehidupan masyarakat Indonesia karena komoditas ini telah turut mempengaruhi tatanan politik dan stabilitas nasional. Selain sebagai makanan pokok lebih dari 95\% penduduk, padi juga menjadi sumber mata pencaharian sebagian besar petani di pedesaan. Laju pertumbuhan penduduk dan tingkat konsumsi beras yang relatif masih tinggi menuntut peningkatan produksi yang berkelanjutan, sementara total luas sawah juga semakin berkurang karena laju konversi lahan menjadi fungsi non pertanian (Balitbangtan,2014), maka penerapan perbaikan teknologi dalam teknik budidaya tanaman padi diperlukan untuk peningkatan hasil per satuan luas.

Lahan sawah merupakan media utama produksi padi dengan produktivitas yang relatif lebih baik dari pada lahan kering dan lahan rawa. Menurut Makarim dan Las (2015), cara yang efektif dan efisien untuk meningkatkan produksi padi nasional secara berkelanjutan adalah meningkatkan produktivitas melalui ketepatan pemilihan komponen teknologi dengan memperhatikan kondisi lingkungan biotik dan abiotik serta pengelolaan lahan yang optimal. Sistem tanam merupakan salah satu komponen teknologi yang dapat mempengaruhi hasil produksi, Saerodji (2013) mengatakan sistem tanam jajar legowo dapat meningkatkan populasi tanaman dengan pengaturan jarak tanam. Hasil penelitian Aribawadan Kariada (2011) menunjukkan bahwa interaksi perlakuan varietas dengan sistem tanam menunjukkan pengaruh yang nyata terhadap hasil gabah kering panen (GKP). Hasil gabah kering panen tertinggi terlihat pada kombinasi perlakuan varietas dengan sistem tanam jajar legowo 2:1 dengan tingkat hasil yang diperoleh 8,15 t/haGKP.

Walaupun dari beberapa hasil penelitian sistem tanam jajar legowo memberikan peningkatan produksi padi yang signifikan, namun pada kenyataannya teknologi ini masih belum sepenuhnya diterapkan oleh petani karena menurut petani ada beberapa kendala dalam penerapan sistem tanam jajar legowo, diantaranya adalah:

1. Penanaman lebih sulit dibandingkan sistem tegel karena jarak tanam dalam baris tidak sama dengan antar baris.

2. Penanaman membutuhkan waktu lebih lama karena jarak tanam tidak simetris dan ada bagian yang dikosongkan, butuh konsentrasi lebih bagi tenaga tanam.

Luas lahan sawah yang ada di Kota Tomohon secara keseluruhan dari tahun ke tahun terjadi penurunan karena alih fungsi menjadi lahan pemukiman. Data BPS Kota Tomohon menunjukkan dari total luas lahan sawah tahun 2013 seluas 702,26 ha terjadi penurunan sampai tahun 2017 dengan luas lahan sawah 649 Ha. Dapat dilihat pada Tabel 1.

Tabel 1. Luas Lahan Sawah di kota Tomohon Tahun 2013- 2017

\begin{tabular}{cccc}
\hline Tahun & Irigasi & Tadah Hujan (Ha) & Total (Ha) \\
\hline 2013 & 702,26 & 182,30 & 884,56 \\
2014 & 702,20 & 182,30 & 884,50 \\
2015 & 505 & 375,60 & 880,60 \\
2016 & 643 & 237 & 880 \\
\hline 2017 & 649 & 230,9 & 879,8 \\
\hline
\end{tabular}

Sumber : BPS Kota Tomohon 2018

Walaupun merupakan salah satu komponen teknologi yang dianjurkan mengantisipasi berkurangnya luas lahan sawah namun baru $25 \%$ petani yang menerapkan sistem tanam jajar legowo, bahkan ada juga petani yang tidak konsisten menerapkan teknologi ini, petani akan menerapkan teknologi ini jika ada bantuan dari pemerintah. Alasan utama belum semua petani yang menerapkan teknologi tanam jajar legowo karena menurut petani keuntungan yang diperoleh dengan menerapkan sistem tanam jajar legowo sama dengan sistem tanam konvensional yang selama ini diterapkan. Menurut Moh. Assad dkk 2017, suatu teknologi akan diterapkan secara berkelanjutan jika secara ekonomi teknologi tersebut memberikan insentif (keuntungan) yang lebih baik dibandingkan dengan teknologi lama. Keuntungan maksimum akan dapat diperoleh jika faktor produksi digunakan secara efisien. Efisiensi ekonomi berfokus pada pengurangan input yang digunakan untuk menghasilkan output yang ditargetkan. Pengurangan input faktor produksi dapat mengurangi biaya produksi dan akhirnya meningkatkan keuntungan yang diterima.

\section{Tingkat Pendidikan.}

\section{Penelitian Terdahulu}

Tingkat pendidikan petani dapat memberikan pengaruh terhadap pengelolaan usahatani, karena akan mempengaruhi pengetahuan dan kemampuan seseorang untuk menerima teknologi baru yang bertujuan untuk meningkatkan produktivitas, (Bananiek S. dan Abidin Z., 2013). Tingkat pendidikan petani responden sebagian besar $(52 \%)$ berpendidikan SMP ini berpengaruh pada tingkat adopsi suatu teknologi hal ini sesuai dengan hasil penelitian dari Putra Utama S., dkk. 2007, yang menyatakan bahwa semakin tinggi tingkat pendidikan petani akan membuat petani mengerti tentang tehnologi budidaya padi sawah sistem tanam jajar legowo dan akan lebih mudah untuk menerapkannya. 


\section{Umur Petani.}

Umur adalah salah satu faktor yang mempengaruhi tingkat kemampuan petani dalam pengelolaan usahataninya. Usia rata-rata petani responden yang menerapkan tehnologi tanam jajar legowo 52,76 tahun, menunjukkan bahwa semakin tua umur petani maka akan lebih inovatif dalam menerapkan inovasi tehnologi, hal ini sesuai dengan hasil penelitian Desya, dkk (2017) Orang yang berumur muda atau berusia produktif tidak menunjukkan lebih inovatif dibanding yang berumur lebih tua.

\section{Pengalaman Usahatani}

Pengalaman usahatani memungkinkan petani mengelolah usahataninya dengan baik serta dapat mengatasi kendala dan hambatan yang ada. Pengalaman juga akan mempengaruhi sikap petani dalam mengambil keputusan berkaitan dengan inovasi baru, karena dibutuhkan keberanian menanggung resiko. Pengalaman usahatani padi petani responden yang menerapkan tehnologi tanam jajar legowo ratarata 25,26 tahun ini menunjukkan para petani memiliki pengalaman yang baik dan mampu berpikir lebih maju dalam mengembangkan usahataninya. Hal ini sejalan dengan penelitian yang dilakukan oleh Mira Apriyani dkk, 2018, yang menunjukkan bahwa pengalaman usahatani mempengaruhi tingkat adopsi inovasi tehnologi Pengelolaan Tanaman Terpadu padi sawah. Petani yang sudah lama berusahatani akan lebih mudah menerapkan tehnologi jajar legowo dibandingkan petani yang memiliki pengalaman yang sedikit, Eldo Rian,dkk. 2018.

4. Keanggotaan dalam Kelompok Tani.

Peraturan Menteri Pertanian Nomor 67/Permentan/SM050/12/2016 menjelaskan Kelompok tani adalah organisasi non formal di perdesaan yang ditumbuh kembangkan dari, oleh dan untuk petani, dengan fungsi sebagai kelas belajar guna meningkatkan pengetahuan, keterampilan dalam berusahatani, sebagai wahana kerja sama dan unit produksi. Kelompok tani pada dasarnya dibentuk untuk menggerakkan sumberdaya manusia yang tergabung didalamnya, membantu petani yang tergabung untuk memfasilitasi segala kebutuhan mulai dari pembelian sarana produksi sampai dengan pasca panen dan pemasaran, Anonimous, 2016. Petani responden sebagian besar (90\%) adalah anggota kelompok tani sehingga dapat menerima inovasi tehnologi dalam meningkatkan produktivitas melalui pembinaan oleh Penyuluh Pertanian dalam dalam setiap pertemuan kelompok. Hal ini sesuai dengan hasil penelitian Nania Agrina dkk (2018) kelompok tani sebagai kelas belajar, wahana kerjasama dan unit produksi mempunyai hubungan yang signifikan dengan penerapan tehnologi baru karena sering berinteraksi dengan Penyuluh Pertanian dalam kegiatan penyuluhan.
Tingkat pendidikan, umur petani, pengalaman usahatani dan keanggotaan dalam kelompok memberikan gambaran karakteristik responden yang merupakan faktor penting dalam penelitian tentang usahatani, karena identitas petani sampel dapat memberikan gambaran secara umum tentang keadaan serta latar belakang petani yang adalah sebagai pengelolah yang merencanakan, mengorganisasi, melaksanakan dan mengevaluasi suatu proses produksi.

5. Luas Lahan Sawah

Lahan pertanian merupakan faktor produksi yang mutlak dibutuhkan dan dalam tidak tergantikan dalam kegiatan usahatani. Luas lahan yang dimilki petani bervariasi dari 0,14 ha sampai 0,7 ha dimana sebagian besar petani memiliki luas lahan 0,14-0,48 ha dan hanya 2 orang petani yang memiliki lahan seluas 0,7 ha. Total luas lahan yang dirata-rata 0,31 ha menunjukkan bahwa luas lahan yang dimiliki petani tergolong sempit $(<0,5 \mathrm{ha})$. Semakin luas lahan yang diusahakan maka semakin tinggi produksi dan pendapatan per kesatuan luasnya. Luas lahan akan menentukan skala usaha yang pada akhirnya akan mempengaruhi keuntungan. Luas sawah di Kecamatan Tomohon Barat terjadi penurunan karena alih fungsi lahan data BPS Kota Tomohon menunjukkan tahun 2013 luas lahan sawah irigasi 702,26 ha dan tahun 2017 luas lahan sawah irigasi 649 ha terjadi penurunan sebesar 53,26 ha sehingga peningkatan produksi dengan penambahan luas lahan sulit dilakukan. Hasil penelitian Suharyanto, dkk 2015, menunjukkan hal yang sama peningkatan produksi melalui penambahan luas lahan sulit dilakukan akibat alih fungsi lahan.

6. Benih

Benih yang digunakan sebesar $34,32 \mathrm{~kg} / \mathrm{ha}$, jumlah bibit yang ditanam 1- 6 bibit perlubang tanam melebihi anjuran, ini mempengaruhi produksi juga terjadi pemborosan dalam pembiayaan dengan demikian mempengaruhi keuntungan yang diperoleh petani. Terbatasnya ketersediaan benih bersertifikat menyebabkan petani mengunakan benih yang berasal dari hasil penanaman sendiri atau petani lain, sehingga tidak terjamin lagi mutu dan kemurnian varietas sehingga mempengaruhi produksi, hal ini sesuai dengan hasil penelitian dari Limbong 2016, yang mengatakan ada perbedaan produksi padi dengan penggunaan sumber benih bersertifikat dan non sertifikat.

7. Pupuk

Penggunaan pupuk Urea rata-rata $57,66 \mathrm{~kg}$ atau $186 \mathrm{~kg} / \mathrm{ha}$, pupuk SP36 $14 \mathrm{~kg}$ atau 45,16 kg/ha, NPK Phonska $24,8 \mathrm{~kg} / \mathrm{ha}$ atau $80 \mathrm{~kg} / \mathrm{ha}$ masih dibawah paket rekomendasi yang dianjurkan yaitu ( Urea $200-300 \mathrm{Kg}$, SP 36 100-150 Kg., NPK Phonska 75-100 Kg). Penggunaan pupuk yang masih rendah karena sering terjadi kelangkaan pupuk bersubsidi pada saat dibutuhkan petani, sementara pupuk non subsidi harganya terlalu mahal. Pemupukan tidak sesuai 
rekomendasi dan tidak tepat waktu dan cara aplikasi berpengaruh pada hasil produksi padi. Hasil penelitian Prabukesuma dkk 2015, menyatakan bahwa waktu aplikasi dan perbedaan dosis pupuk memberikan perbedaan pada parameter tinggi tanaman, anakan produktif, panjang malai, dan bobot kering gabah.

8. Tenaga Kerja

Faktor produksi tenaga kerja mutlak diperlukan dalam kegiatan usahatani karena akan mempercepat proses produksi. Keterbatasan ketersediaan tenaga kerja menyebabkan harga tenaga kerja menjadi mahal dan ini sering menjadi kendala bagi petani. Penggunaan tenaga kerja sebesar 39, 67 HKSP atau 127,97 HKSP/ha dengan harga tenaga kerja Rp. 150.000,- per HKSP menuntut petani untuk menggunakan tenaga kerja seefisien mungkin karena akan mempengaruhi tingkat keuntungan yang diperoleh petani. Penggunaan tenaga kerja yang berlebihan juga dapat mengurangi produksi yang dihasilkan.

9. Produksi

Produksi padi dengan penerapan sistem tanam legowo setara $5.567,9 \mathrm{~kg}$ GKP/ha masih lebih tinggi dibandingkan dengan rata-rata secara keseluruhan usahatani padi sawah di Kota Tomohon $(5.105 \mathrm{~kg} / \mathrm{ha})$ BPS kota Tomohon 2018. Walaupun produksi lebih tinggi tetapi masih memungkin untuk peningkatan produksi beras, karena dari beberapa hasil penilitian sistem tanam jajar legowo dapat meningkatkan produksi sampai 8,5 ton GKP/ha.

10. Analisis Keuntungan Usahatani

Kenaikan dan penurunan produksi dapat terjadi karena perubahan penggunaan faktor-faktor produksi. Produk-produk pertanian dihasilkan dari kombinasi penggunaan faktor produksi lahan, tenaga kerja dan modal (pupuk, benih, obat-obatan), Soekartawi 2006. Kurang tepatnya jumlah dan kombinasi faktor produksi mengakibatkan rendahnya produksi yang dihasilkan atau tingginya biaya produksi. Rendahnya produksi dan tinggnya biaya produksi akan mengakibatkan rendahnya keuntungan petani. Keuntungan rata-rata yang diperoleh petani sebesar Rp. 1.483.768, hasil analisis efisiensi ekonomi penggunaan faktor-faktor produksi belum efisien karena nilai efisiensi ekonomi lebih besar 1 dan lebih kecil 1. Untuk memperoleh keuntungan maksimal petani dapat menambah atau mengurangi penggunaan faktor produksi.

11. Analisis Pengaruh Penggunaan Faktor-Faktor Produksi

Output yang maksimal dalam mengelola suatu usahatani dapat dicapai jika hubungan antara faktorfaktor produksi dengan hasil produksi dapat diketahui, sehingga faktor produksi dapat ditambahkan atau dikurangi. Hubungan antara faktor-faktor produksi dan hasil produksi padi dapat diketahui dengan analisis regresi liniear berganda.
Hasil analisis regresi linear berganda menunjukkan bahwa nilai $\mathrm{R}^{2}$ sebesar 0,989 artinya 98,9 persen pengaruh variabel dependent $(\mathrm{Y})$ dapat dijelaskan oleh variabel-variabel bebas (Xi) sedangkan sisanya sebesar 1,1 persen dipengaruhi oleh faktor lain diluar model. Nilai adjusted $R^{2} 0,987$ artinya sebanyak 98,7 persen variasi dari variabel dependent (produksi beras) dapat dijelaskan oleh variabel independent (Luas Lahan, Benih, Pupuk Urea, Pupuk SP 36, Pupuk NPK Phonska dan Tenaga Kerja), sedangkan sisanya sebesar 1,3 persen dijelaskan oleh variasi dari variabel diluar model. Nilai $\mathrm{F}$ hitung sebesar 482,54 > F tabel artinya variabel (Luas Lahan, Benih, Pupuk Urea, Pupuk SP 36, Pupuk NPK Phonska dan Tenaga Kerja) secara bersama-sama mempengaruhi produksi beras.

Faktor produksi luas lahan berpengaruh sangat nyata terhadap produksi padi dengan koefisien regresi sebesar 2600,185 yang berarti bahwa kenaikan luas lahan sebesar satu ha akan meningkatkan produksi sebesar 2600,185 kg. Dengan demikian semakin bertambah luas lahan yang digunakan maka semakin tinggi produksi padi.

Faktor produksi luas lahan memberikan pengaruh yang sangat besar terhadap hasil produksi dibandingkan dengan faktor produksi yang lain terlihat nilai koefisien estimasi yang lebih besar dibandingkan dengan faktor produksi yang lain, hal yang sama ditunjukkan hasil penelitian Suharyanto, dkk 2015 yang mengatakan bahwa faktor produksi luas lahan merupakan variabel yang sangat elastis mempengaruhi produksi padi dibandingkan faktor produksi lainnya.

Faktor produksi benih mempunyai nilai koefisien regresi sebesar $(-0,085)$ yang berarti bahwa penambahan penggunaan benih sebesar satu kilogram akan menurunkan produksi padi sebesar 4,085 Kg. Hal ini terjadi terlalu banyak menyebabkan populasi per lubang tanam tinggi, terjadi persaingan antar tanaman dalam penyerapan unsur hara, oksigen dan sinar matahari sehingga produksi padi menjadi rendah. Hal yang sama sesuai dengan hasil penelitian Respikasari, dkk 2014 dan Akbar, dkk 2017 yang mengatakan bahwa penggunaan benih yang berlebihan akan menurunkan hasil produksi padi karena akan terjadi persaingan antar tanaman dalam memanfaatkan unsur hara.

Hasil analis regresi linear menunjukan faktor produk pupuk (Urea, SP 36 dan NPK Phonska) secara singnifikan mempengaruhi hasil produksi padi sawah, hal yang sama dilaporkan oleh Onibala, dkk 2017 dalam penelitiannya, yang menyatakan bahwa faktor produksi pupuk Urea, SP 36 dan NPK Phonska memberikan pengaruh yang signifikan terhadap produksi padi sawah.

Faktor produksi pupuk urea berpengaruh nyata terhadap produksi padi dan memiliki nilai koefisien regresi sebesar 0,835 yang berarti bahwa penambahan penggunaan pupuk urea sebesar satu kilogram akan meningkatkan produksi padi sebesar $0,835 \mathrm{Kg}$. 
Faktor produksi pupuk SP 36 berpengaruh nyata terhadap produksi padi dengan nilai koefisien regresi sebesar 2,648 yang berarti penambahan pupuk SP 36 sebesar satu kilogram akan meningkatkan produksi sebesar $2,648 \mathrm{Kg}$. Faktor produksi pupuk NPK Phonska berpengaruh nyata terhadap produksi padi dengan nilai koefisien regresi sebesar 1,212 yang berarti penambahan pupuk NPK Phonska sebesar satu kilogram akan meningkatkan produksi sebesar $1,212 \mathrm{Kg}$.

Faktor produksi tenaga kerja mempunyai nilai koefisien regresi sebesar -0,301 yang berarti bahwa penambahan tenaga kerja sebesar satu HKSP akan mengurangi produksi sebesar $0,301 \mathrm{~kg}$.

12. Analisis Efisiensi Ekonomi Penggunaan Faktor-

Faktor Produksi

Analisis efisiensi diperlukan untuk membantu petani mengalokasikan faktor-faktor produksi agar tidak terjadi pemborosan. Efisiensi dalam penggunaan input sangat penting dan sangat berpengaruh terhadap hasil produksi dan keuntungan. Petani yang rasional akan berprinsip bagaimana dalam proses produksinya bisa mencapai tingkat efisiensi ekonomi tertinggi. Efisiensi ekonomi tertinggi dari penggunaan faktor-faktor produksi tercapai apabila perbandingan nilai produk marginal dengan harga masing-masing faktor produksi sama dengan satu. Pada penelitian ini penghitungan efisiensi ekonomi penggunaan faktorfaktor produksi menggunakan pendekatan keuntungan maksimum. Hal ini menunjukkan nilai perbandingan tambahan produksi (NMPX) dengan harga faktor produksi (PX) tidak sama dengan satu yang berarti penggunaan faktor-faktor produksi secara parsial belum mencapai efisiensi ekonomi tertinggi.

Nilai efisiensi untuk faktor produksi luas lahan lebih besar dari satu yang berarti secara ekonomis alokasi penggunaan faktor produksi luas lahan pada tingkat 0,31 ha belum efisien sehingga untuk meningkatkan produksi luas lahan perlu ditambah. Hasil analisis koefisien regresi parsial menunjukkan bahwa luas lahan mempunyai nilai yang paling besar yang berarti luas lahan paling berpengaruh terhadap produksi padi. Nilai efisiensi yang lebih besar dari satu merupakan indikator bahwa penggunaan faktor produksi berupa luas lahan dalam penerapan sistem tanam legowo di Kecamatan Tomohon Barat belum efisien. Semakin berkurangnya luas lahan sawah di Kecamatan Tomohon Barat karena alih fungsi lahan maka upaya peningkatan produksi dapat dilakukan dengan pencetakan sawah baru atau lahan optimasi lahan sawah terutama untuk sawah tadah hujan atau dengan cara meningkatkan index pertanaman.
Nilai efisiensi faktor produksi benih adalah kurang dari satu yang berarti penggunaan benih pada usahatani padi sistem legowo tidak efisien secara ekonomi. Secara ekonomis alokasi penggunaan benih padi sawah di Kecamatan Tomohon Barat pada tingkat $34,32 \mathrm{~kg} / \mathrm{ha}$ tidak efisien lagi. Benih yang digunakan petani padi sawah terlalu banyak melebihi anjuran 20 $\mathrm{kg} / \mathrm{ha}$, sehingga upaya yang dapat dilakukan untuk meningkatkan produksi adalah dengan mengurangi penggunaan benih dengan cara menanam 1-3 benih per lubang tanam (Benu et al., 2011). Selain hal itu penggunaan benih unggul dan bermutu juga dipandang merupakan cara yang baik dalam rangka peningkatan produksi padi di daerah penelitian.

Nilai efisiensi faktor produksi pupuk urea lebih besar satu yang berarti secara ekonomis alokasi penggunaan pupuk urea belum mencapai efisiensi ekonomi tertinggi. Tryono et all (2013) menyatakan bahwa effisiensi penggunaan pupuk $\mathrm{N}$ dilakukan dengan pemberian pupuk $\mathrm{N}$ sesuai dengan rekomendasi dengan metode bagan warna daun yang dapat disesuaikan dengan dosis dan waktu yang tepat dalam pemberian pupuk $\mathrm{N}$.

Pupuk SP36 dan pupuk NPK Phonska secara ekonomi penggunaannya juga belum efisien karena nilai efisiensi lebih besar satu. Guna meningkatkan efisiensi pemupukan padi sawah diperlukan rekomendasi pemupukan padi sawah spesifik lokasi, dimana rekomendasi pupuk didasarkan pada status hara tanah dan kebutuhan hara tanaman, Anonimous 2005.

Nilai efisiensi faktor produksi tenaga kerja lebih kecil satu (-0,481yang berarti bahwa penggunaan tenaga kerja juga tidak efisien secara ekonomi, untuk mencapai efisiensi ekonomi sehingga diperoleh keuntungan yang maksimal, tenaga kerja perlu dikurangi. Tenaga kerja yang bisa dikurangi yaitu pada saat panen dengan menggunakan combine treesher, saat persemaian hingga tanam bibit juga dapat ditekan dengan menggunakan mesin tanam pindah bibit padi (transplanter). Unadi dan Suparlan (2011) menyatakan bahwa mesin transplanter selain berfungsi untuk mengisi kekurangan tenaga kerja manusia dan tingkat upah yang semakin mahal, maka penggunaan mesin transplanter dapat meningkatkan efisiensi usahatani melalui penghematan tenaga, waktu dan biaya produksi.

\section{Perumusan Masalah}

Berdasarkan permasalahan tersebut maka dirumuskan masalah sebagai berikut :

1. Apakah keuntungan yang diperoleh petani dengan penerapan sistem tanam Jajar Legowo secara ekonomi sudah efisien.

2. Faktor produksi apa saja yang mempengaruhi hasil produksi tanaman padi dengan penerapan sistem tanam jajar legowo. 
3. Apakah penggunaan faktor produksi pada penerapan sistem tanam jajar legowo secara ekonomi sudah efisien.

\section{Tujuan Penelitian}

Tujuan dari penelitian ini adalah :

1. Menganalisa berapa besar keuntungan yang diperoleh dengan penerapan sistem tanam jajar legowo.

2. Menganalisis faktor-faktor produksi apa saja yang mempengaruhi produksi padi dengan penerapan sistem tanam jajar legowo.

3. Menganalisa apakah penggunaan faktor produksi yang di alokasikan petani dengan sistem tanam legowo secara ekonomi sudah efisien.

\section{Manfaat Penelitian}

Manfaat dari penelitian ini adalah

1. Bahan informasi bagi petani tentang penggunaan faktor produksi dalam mencapai efisiensi ekonomi.

2. Bahan masukan bagi pemerintah/instansi terkait untuk meningkatkan produksi padi dalam mewujudkan program kedaulatan pangan.

3. Bahan informasi bagi penulis dan peneliti lain yang akan melanjutkan dan mengembangkan penelitian ini.

\section{METODE PENELITIAN}

\section{Tempat dan Waktu Penelitian}

Lokasi penelitian dilaksanakan di Kecamatan Tomohon Barat, Kota Tomohon, Provinsi Sulawesi Utara. Penelitian dilaksanakan dari bulan Januari 2019 sampai dengan April 2019. Lokasi penelitian dipilih secara Purposive dengan pertimbangan Kecamatan Tomohon Barat merupakan Sentara produksi beras di Kota Tomohon dengan total luas sawah 447,40 ha (52\% Total Luas Sawah Kota Tomohon).

\section{Bahan dan Alat}

Bahan dan Alat yang digunakan dalam penelitian ini meliputi kuesioner untuk mengumpulkan data primer dengan cara wawancara langsung dengan petani responden, kamera untuk pengambilan gambar visual kegiatan penelitian/ perekaman data sekunder dari instansi terkait, Kalkulator, Laptop dan Alat tulis menulis.

\section{Metode Penelitian}

Metode penelitian yang digunakkan dalam penelitian ini adalah metode survey di Kelurahan yang ada lahan sawah di Kecamatan Tomohon Barat dengan teknik wawancara kepada petani responden. Penentuan sampel dilakukan dengan metode quota sampling sebanyak 50 orang diambil dari 7 (Tujuh) Kelurahan yang ada di Kecamatan Tomohon Barat dengan mem-pertimbangkan luas lahan dan tujuan usahatani (commercial farm).

\section{Variabel dan Pengukuran}

Variabel yang akan diteliti adalah :

1. Umur

2. Pendidikan

3. Pengalaman Usaha

4. Keanggotaan dalam kelompok

5. Luas Lahan

6. Benih

7. Pupuk (Urea,SP36 dan NPK)

8. Tenaga kerja (HKSP)

9. Produksi

10. Harga

Konsep pengukuran variabel sebagai berikut :

1. Umur adalah usia petani responden pada saat pengambilan data.

2. Pendidikan adalah tingkat pendidikan tertinggi petani responden.

3. Pengalaman Usaha adalah lamanya petani responden dalam mengelola usahatani padi sawah.

4. Keanggotaan dalam kelompok adalah keterlibatan petani responden dalam kelompok tani.

5. Luas lahan adalah luas lahan yang ditanami padi sawah diukur dalam hektar, sedangkan harga lahan dinilai berdasarkan harga sewa selama satu kali musim tanam dalam rupiah per hektar.

6. Benih adalah jumlah benih yang digunakan dalam satu kali musim tanam diukur dalam kilogram, harga benih dalam rupiah per kilogram.

7. Pupuk Urea adalah jumlah pupuk Urea yang digunakan dalam satu kali musim tanam diukur dalam kilogram, harga pupuk dalam rupiah perkilogram.

8. Pupuk SP36 adalah jumlah pupuk SP36 yang digunakan dalam satu kali musim tanam diukur dalam kilogram, harga pupuk dalam rupiah perkilogram.

9. Pupuk Phonska adalah jumlah pupuk Phonska yang digunakan dalam satu kali musim tanam diukur dalam kilogram, harga pupuk dalam rupiah perkilogram.

10. Tenaga kerja adalah jumlah tenaga kerja yang digunakan dalam satu kali musim tanam dalam Hari Kerja Setara Pria (HKSP) dimana semua tenaga kerja dan alat dan mesin pertanian yang digunakan (pratanam sampai panen) dikonversikan kedalam tenaga kerja laki-laki, sedangkan harga tenaga kerja dinilai berdasarkan upah perhari. 
11. Produksi adalah jumlah produksi yang dihasilkan oleh setiap petani selama satu kali musim tanam diukur dalam kilogram.

12. Harga produksi dinyatakan dalam rupiah per kilogram.

\section{Analisis Data}

Data dalam penelitian ini terdiri dari data Sekunder dan data primer. Data sekunder diperoleh dari Balai Penyuluhan Pertanian Peternakan Perikanan dan Kehutanan (BP3K) kecamatan Tomohon Barat, Dinas Pertanian dan peternakan Kota Tomohon dan Badan Pusat Statistik Kota Tomohon. Data primer diperoleh dari hasil wawancara dengan menggunakan kuesioner terhadap responden, data yang dikumpulkan direkap dan ditabulasi. Data umur, pendidikan, pengalaman usaha dan keanggotaan dalam kelompok memberikan gambaran tentang karakteristik responden. Data total penerimaan dan total biaya untuk menganalisa keuntungan usahatani. Data penggunaan faktor produksi berupa lahan, benih, pupuk, tenaga kerja, penggunaan alsintan untuk analisis pengaruh faktor produksi terhadap hasil produksi dan analisis efisiensi ekonomi penggunaan factor produksi.

1. Analisis Keuntungan Usahatani.

Keuntungan usahatani dihitung dengan cara mengurangi total penerimaan dengan total biaya, dengan rumus :

$$
\pi=\mathrm{TR}-\mathrm{TC}
$$

Dimana :

$\pi=$ Keuntungan

$\mathrm{TR}=$ Total Revenue $($ Penerimaan Total $)$

$\mathrm{TC}=$ Total Cost $($ Biaya Total $),($ Biaya tetap + Biaya variable)

2. Analisis Pengaruh Faktor Produksi

Analisis pengaruh penggunaan faktor produksi terhadap hasil produksi padi menggunakan analisis linear berganda. Hubungan antara faktorfaktor produksi dengan hasil produksi dianalisis menggunakan regresi linear berganda, dengan rumus:

$Y=a+b_{1} X_{1}+b_{2} X_{2}+b_{3} X_{3}+b_{4} X_{4} b_{5} X_{5}+b_{6} X_{6}$ Dimana :

$\mathrm{Y}=$ Produksi $(\mathrm{Kg})$

$\mathrm{X}_{1}=$ Luas Lahan $(\mathrm{Ha})$

$\mathrm{X}_{2}=\operatorname{Benih}(\mathrm{Kg})$

$\mathrm{X}_{3}=$ Pupuk Urea $(\mathrm{Kg})$

$\mathrm{X}_{4}=$ Pupuk SP $36(\mathrm{Kg})$

$\mathrm{X}_{5}=$ Pupuk NPK $(\mathrm{Kg})$

$\mathrm{X}_{6}=$ Tenaga Kerja $(\mathrm{HOK})$

$\mathrm{a}=$ Konstanta

$\mathrm{b}=$ Koefisien regresi
3. Analisis Efisiensi Ekonomi Penggunaan Faktor Produksi

Analisis efisiensi ekonomi penggunaan faktor produksi dilakukan untuk menguji apakah penggunaan faktor produksi sudah mencapai kondisi yang optimal (efisiensi ekonomi), dengan melihat perbandingan antara produksi fisik marginal faktor produksi dengan harga faktor produksi. Penghitungan efisiensi ekonomi penggunaan faktorfaktor produksi menggunakan pendekatan keuntungan maksimum. Keuntungan maksimum akan tercapai apabila produk marginal suatu faktor produksi (NPMxi) sama dengan harga faktor produksi tersebut (Pxi).

$$
\begin{gathered}
\frac{\mathrm{NPMX}_{1}}{\mathrm{PX}_{1}}=\frac{\mathrm{NPMX}_{2}}{\mathrm{PX}_{2}}=\frac{\mathrm{NPMXn}}{\mathrm{PX}_{3}}=\frac{\mathrm{NPMXn}}{\mathrm{PXn}}=1 \\
\mathrm{NPMXi}=\frac{\text { bi. Y.Py }}{\mathrm{Xi}}
\end{gathered}
$$

Keterangan :

bi = Elastisitas produksi

Py $=$ Harga beras rata-rata $(\mathrm{Rp} / \mathrm{Kg})$

$\mathrm{Y}=$. Hasil produksi beras

$\mathrm{X}_{\mathrm{i}}=$ Faktor produksi

$\mathrm{Px}=$ Harga faktor produksi

Apabila nilai NPMxi lebih besar dari satu berarti penggunaan faktor produksi Xi belum mencapai effisiensi ekonomi tertinggi dan untuk mencapainya input Xi ini perlu ditambah, dan jika nilai NPMxi/Pxi lebih kecil dari satu berarti penggunaan faktor produksi $\mathrm{Xi}$ tidak efisien secara ekonomi maka penggunaanya perlu dikurangi.

\section{HASIL DAN PEMBAHASAN}

\section{Hasil Penelitian}

\section{Tingkat Pendidikan}

Hasil analisis data menunjukkan Persentase tingkat pendidikan tertinggi petani responden adalah yang berpendidikan terakhir D3 sebanyak 2 orang petani $(4 \%)$, petani yang berpendidikan SLTA sebesar $36 \%$ atau sebanyak 18 orang petani, petani yang berpendidikan SLTP sebesar $52 \%$ atau sebanyak 26 0rang petani dan petani yang

\begin{tabular}{|c|c|c|}
\hline Tingkat Pendidikan & Jumlah Petani (Orang) & Persentase $(\%)$ \\
\hline SD & 5 & 10 \\
\hline SLTP & 26 & 52 \\
\hline SLTA & 17 & 34 \\
\hline D3 & 2 & 4 \\
\hline Jumlah & 50 & 100 \\
\hline
\end{tabular}
berpendidikan SD sebesar $4 \%$ atau sebanyak 5 orang, Dapat dilihat pada Tabel 2. 


\section{Umur Petani}

Hasil analisis data menunjukkan umur petani responden terendah 26 tahun dengan rata-rata usia petani 52,76 tahun. Sebanyak 5 orang petani $(10 \%)$ petani berumur diatas 65 tahun, 25 orang petani $(50 \%)$ berumur 52-65, tahun sebanyak 16 petani (32\%) berumur 39-51 tahun dan sebanyak 4 petani $(8 \%)$ berumur $26-38$ tahun, Dapat dilihat pada Tabel 3 .

\begin{tabular}{lcr} 
Tabel 3. Karakteristik Umur Petani & \\
\hline Umur (Tahun) & Jumlah Petani (Org) & Persentase (\%) \\
\hline $26-38$ & 4 & 8 \\
$39-51$ & 16 & 32 \\
$52-65$ & 25 & 50 \\
$>65$ & 5 & 10 \\
\hline Jumlah & 50 & 100 \\
\hline Rata-Rata 52,76 Tahun & \\
\hline \multicolumn{2}{l}{ Sumber: Analisis Data Primer, 2019 }
\end{tabular}

\section{Pengalaman Usahatani}

Petani responden mempunyai pengalaman usahatani terendah 11 tahun dalam mengelolah usahatani dengan rata-rata pengalaman usahatani 25,26 Tahun. Sebanyak 8 orang petani $(16 \%)$ memilki pengalaman usaha diatas 37 tahun, sebanyak 9 orang petani (18\%) memiliki pengalaman usahatani 29-37 tahun dan sebanyak 21 orang petani memiliki pengalaman usahatani $20-28$ tahun dan 12 orang petani (24\%) memiliki pengalaman usaha11-19 tahun, Dapat dilihat pada Tabel 4.

\begin{tabular}{lcr}
\multicolumn{3}{l}{ Tabel 4. Pengalaman Usahatani } \\
\hline Pengalaman (tahun) & Jumlah Petani (Org) & Persentase (\%) \\
\hline $11-19$ & 12 & 24 \\
$20-28$ & 21 & 42 \\
$29-37$ & 9 & 18 \\
$>37$ & 8 & 16 \\
\hline Jumlah & 50 & 100 \\
\hline \multicolumn{3}{c}{} \\
\hline Sumber : Analisis Data primer 2019
\end{tabular}

\section{Keanggotaan Dalam Kelompok Tani}

Lahan merupakan faktor produksi yang mutlak dibutuhkan dan tidak dapat tergantikan dalam melakukan usahatani. Luas Lahan Sawah dapat dilihat pada Tabel 5.

Tabel 5. Keanggotaan dalam Kelompok Tani

\begin{tabular}{lcr}
\hline \multicolumn{1}{c}{ Status Dalam } & Jumlah $($ Org) & Persentase (\%) \\
\hline Pelompok & & 20 \\
Angurus & 10 & 70 \\
Non Anggota & 35 & 10 \\
\hline Jumlah & 5 & 100 \\
\hline Sumber : Analisis Data primer 2019 &
\end{tabular}

\section{Luas Lahan Sawah}

Hasil analisis data menunjukkan bahwa faktor produksi luas lahan padi sawah yang dimiliki petani rata-rata 0,31 ha, dengan luas lahan terendah yang dikelola petani 0,14 ha dan yang tertinggi 0,7 ha. Sebanyak 22 orang petani (44\%) memiliki lahan seluas $0,14-0,28$ ha, sebanyak 20 orang petani (40\%) memiliki luas lahan $0,29-0,43$ ha, sebanyak 6 orang petani memiliki lahan seluas $0,44-0,5$ ha dan 2 orang petani (4\%) memiliki lahan >0,5 ha, Dapat dilihat pada Tabel 6 .

\begin{tabular}{ccr} 
Tabel 6. Luas Lahan & & \\
\hline Luas Lahan (ha) & Jumlah (orang) & Persentase (\%) \\
\hline $0,14-0,28$ & 22 & 44 \\
$0,29-0,43$ & 20 & 40 \\
$0,44-0,5$ & 6 & 12 \\
$>0,5$ & 2 & 4 \\
\hline Jumlah & 50 & 100 \\
\hline Rata-Rata 0,31 & &
\end{tabular}

Sumber : Analisis Data primer 2019

\section{Benih}

Benih yang digunakan petani rata- rata 10,64 $\mathrm{kg}$ per rata-rata luas tanam atau $34,32 \mathrm{~kg} / \mathrm{ha}$, benih berasal dari hasil penanaman petani dengan haga benih Rp. 8.000/kg., varietas yang digunakan antara lain varietas Cigeulis dan Serayu. Petani responden menerapkan sistem tanam legowo 2:1, 3:1 dan 4:1, benih disemaikan setelah kurang lebih umur 20 hari bibit ditanam dengan jumlah $1-6$ bibit perlubang tanam.

7. Pupuk.

Petani responden umumnya melakukan pemupukan dengan pupuk buatan terutama pupuk Urea, SP36 dan Phonska, dimana jumlah takaran pupuk masih beragam yakni pupuk Urea $57,66 \mathrm{~kg}$ per rata-rata luas tanam, SP36 14,00 kg per rata-rata luas tanam dan Pupuk NPK Phonska 24,8 kg per rata-rata luas tanam. Pemupukan $\mathrm{N}$ umumnya dilakukan dua kali yaitu pada umur $7-10$ hari setelah tanam (HST) bersamaan dengan pupuk P dan $\mathrm{K}$ sebagai pupuk dasar, pemupukan $\mathrm{N}$ yang kedua pada stadia anakan aktif umur 21 - 28 HST. Pupuk yang digunakan adalah pupuk bersubsidi dengan harga Rp. 1.800/kg untuk urea, SP 36 Rp. 2.600 dan NPK phonska Rp. 2.300.

8. Tenaga Kerja

Kegiatan usahatani padi sawah antara lain pengolahan tanah, pencabutan bibit, penanaman, perbaikan pematang, pemupukan, penyiangan, panen dan pasca panen pada umumnya dikerjakan oleh tenaga harian atau borongan baik tenaga kerja dalam keluarga maupun tenaga kerja luar keluarga. Upah tenaga kerja sebesar Rp. 150.000 /hari untuk tenaga kerja pria dan Rp. 125.000 /hari untuk tenaga kerja wanita. Adapun upah tenaga borongan sesuai dengan pekerjaan antara lain: pembersihan pematang menggunakan mesin pemotong rumput (mesin pangkas) dengan biaya Rp. 300.000 - Rp. 
350.000 /ha, pengolahan tanah dikerjakan menggunakan mesin/traktor dengan biaya Rp 1.200.000/ha, perontokan padi menggunakan mesin perontok dengan biaya Rp. 1.350.000/ kg. Seluruh biaya tenaga kerja baik harian maupun borongan termasuk pengunaan alat dan mesin pertanian pratanam sampai panen dikonversi menjadi tenaga kerja pria atau HKSP (Hari Kerja Setara Pria) dengan nilai yaitu total sewa alsintan Rp. 830.900 /rata-rata luas tanam atau setara 5,53 HKSP, tenaga kerja wanita Rp. 1.365.000 /rata-rata luas tanam atau setara 9,1 HKSP, Tenaga kerja pria Rp. 3.745.500 /rata-rata luas tanam atau 24,97 sehingga total tenaga kerja yang digunakan 39,61 HKSP.

\section{Produksi}

Produksi yang dihasilkan petani responden dengan penerapan sistem tanam jajar legowo rata-rata perluas tanam sebesar $943 \mathrm{~kg}$ beras atau setara dengan $1.726 \mathrm{~kg}$ GKP jika dikonversi ke Ha, maka produksi padi sebesar 5.567,7 kg GKP. Petani respon menjual hasil produksi dalam bentuk beras dengan harga $\mathrm{Rp}$. 10.000 per $\mathrm{kg}$.

10. Analisa Keuntungan Usahatani

Keuntungan usahatani dihitung dengan menggunakan rumus :

$$
\pi=\mathrm{TR}-\mathrm{TC}
$$

Keuntungan usahatani $=$ Total Penerimaan - Total Biaya.

Hasil analisis data, biaya Total yang dikeluarkan petani rata-rata sebesar Rp. 8.009.232,dan produksi rata-rata sebesar $943 \mathrm{Kg}$ beras, dengan harga jual Rp. 10.000,- perkilogram maka penerimaan total rata-rata sebesar Rp.9.430.000,-.

Dari hasil analisis data pada, Penerimaan total rata-rata perluas tanam Rp. 9.493.000,- dengan total biaya Rp. 8.009.232,- sehingga keuntungan petani adalah:.

Keuntungan rata-rata $=$ Rp. 9.493.000 - Rp. 8.009.232

$$
=\text { Rp. 1.483.768,- }
$$

\section{Analisis Pengaruh Faktor - Faktor Produksi}

Hasil analisis yang dilakukan dengan bantuan program SPSS 16 untuk melihat pengaruh faktor faktor produksi $(\mathrm{Xi})$ terhadap produksi $(\mathrm{Y})$ pada taraf kepercayaan $95 \%$ menunjukkan nilai $\mathrm{R}^{2}$ sebesar 0,989, nilai adjusted $\mathrm{R}^{2}$ sebesar 0,987 , nilai $\mathrm{F}$ hitung sebesar 482,54. Dapat dilihat pada Tabel 7.

Tabel 7. Koefisien Regresi Pengaruh Faktor- Faktor

\begin{tabular}{|c|c|c|c|}
\hline Model & Koefisien Regresi & t Hitung & Signifikan \\
\hline Konstanta & 106,356 & 3,590 & 0,001 \\
\hline Luas Lahan & 2600,185 & 15.139 & .000 \\
\hline Benih & -4.085 & -0.761 & 0.452 \\
\hline Pupuk Urea & 0,835 & 1,312 & 0.199 \\
\hline Pupuk SP36 & 2,648 & 1,495 & 0.144 \\
\hline Pupuk NPK & 1,212 & 1,633 & 0.122 \\
\hline Tenaga Kerja & $-0,301$ & $-1,013$ & 0.318 \\
\hline $\mathrm{R}^{2}$ & 0,989 & & \\
\hline Adjusted $\mathrm{R}^{2}$ & 0,987 & & \\
\hline F Hitung & 482,54 & & \\
\hline
\end{tabular}
Produksi terhadap Produksi
Tabel 7 menunjukkan bahwa faktor produksi lahan, berpengaruh nyata pada $\alpha 0,01 \%$, faktor produksi benih dan tenaga kerja tidak berpengaruh nyata. Faktor produksi pupuk Urea dan SP 36 berpengaruh nyata pada $\alpha 20 \%$, pupuk NPK Phonska berpengaruh nyata pada $\alpha 10 \%$, Hasil analisis data menghasilkan model sebagai berikut : $\mathrm{Yi}=106,356+2600,185 \mathrm{X} 1-4.085 \mathrm{X} 2+0,835 \mathrm{X} 3+$ $2,648 \mathrm{X} 4+1,212 \mathrm{X} 5-0,301 \mathrm{X} 6$

Keterangan :

$\mathrm{Y}=$ Hasil produksi beras $(\mathrm{Kg})$

$\mathrm{X} 1=$ Luas lahan $(\mathrm{Ha})$

$\mathrm{X} 2=$ Benih $(\mathrm{Kg})$

$\mathrm{X} 3$ = Pupuk Urea $(\mathrm{Kg})$

X4 = Pupuk SP-36 $(\mathrm{Kg})$

$\mathrm{X} 5=$ Pupuk Phonska $(\mathrm{Kg})$

$\mathrm{X} 6$ = Tenaga kerja (HKSP)

\section{Analisis Efisiensi Ekonomi Penggunaan Faktor Produksi \\ Hasil analisis efisiensi ekonomi penggunaan} faktor-faktor produksi usahatani padi sawah di Kecamatan Tomohon Barat Kota Tomohon, menunjukkan bahwa nilai perbandingan antara nilai produk marginal dengan harga masing-masing faktor produksi adalah 39.812,187 untuk faktor produksi luas lahan, $-555,952$ untuk faktor produksi benih, 760,374 untuk faktor produksi pupuk urea, 690,590 untuk faktor produksi pupuk SP 36, 201,710 untuk faktor produksi pupuk NPK dan -0,481 untuk faktor produksi tenaga kerja. Rata-rata nilai efisiensi secara keseluruhan sebesar 6.704,07, Dapat dilihat pada Tabel 8.

Tabel 8. Analisis Efisiensi Ekonomi Penggunaan Faktor-Faktor Produksi

\begin{tabular}{lcccc}
\hline \multicolumn{1}{c}{$\begin{array}{c}\text { Faktor } \\
\text { Produksi }\end{array}$} & NPMXi & PXi (Rp) & Efisiensi & Keterangan \\
\hline LuasLahan & $76.624 .374 .854,82$ & $2.000,000$ & $39.812,187$ & Belum Efisien \\
Benih & $-4.447 .613,252$ & 8.000 & $-555,952$ & Tidak Efisien \\
Pupuk Urea & $137.472,338$ & 1.800 & 76,374 & Belum Efisien \\
PupukSP36 & $1.795 .533,143$ & 2.600 & 690,590 & Belum Efisien \\
Pupuk NPK & $463.932,097$ & 2.300 & 201,710 & Belum Efisien \\
TenagaKerja & $-72.138,172$ & 150.000 & $-0,481$ & Tidak Efisien \\
\hline Produksi rata-rata & $949,30 \mathrm{Kg}$ \\
\hline Harga & $\mathrm{Rp} .10 .00 / \mathrm{Kg}$ \\
\hline Total & $60.224,428$ \\
\hline Rata-Rata & $6.704,07$ \\
\hline Sumber : Data Primer diolah, Tahun 2019
\end{tabular}

\section{KESIMPULAN DAN SARAN}

\section{Kesimpulan}

1. Keuntungan usahatani padi sawah dengan penerapan sistem tanam legowo,petani di Kecamatan Tomohon Barat kota Tomohon belum maksimum, belum mencapai efisiensi ekonomi. 
2. Faktor produksi mempengaruhi produksi padi adalah Luas Lahan, Benih, Pupuk ( Urea, SP 36 dan NPK Phonska) dan Tenaga Kerja.

3. Penggunaan faktor produksi Luas Lahan, Pupuk ( Urea, SP 36 dan NPK Phonska) belum mencapai efisiensi ekonomi, penggunaan faktor produksi Benih dan Tenaga Kerja tidak efisien.

\section{Saran}

Berdasarkan hasil penelitian disarankan

kepada petani untuk :

1. Mengalokasikan penggunaan faktor produksi secara efisien agar diperoleh keuntungan maksimum.

2. Mengurangi penggunaaan faktor-faktor produksi yang tidak efisien dan menambah penggunaan faktor-faktor produksi yang belum efisien.

3. Meningkatkan pengetahuan dan ketrampilan dalam tehnik budidaya padi sistem tanam jajar legowo.

\section{DAFTAR PUSTAKA}

Anonimous, 2005. Panduan Lengkap Budidaya Tanaman Padi. http://dasarpertanian.blogspot.com. Diakses tanggal18 Desember 2018.

Anonimous, 2016. Pembinaan Kelompok Tani. http://agronomi pertanian. blogspot.com. Diakses tanggal 2 Juni 2019.

Anonimous, 2017. Analisis Regresi Linear Berganda. httpl/:dawaisimfoni wordpress.com. Diakses tanggal 26 Pebruari 2019.

Anonimous, 2018. Tomohon Dalam Angka. Badan Pusat Statistik Kota Tomohon.

Aribawa, I.B dan IK.Kariada, 2011. Pengaruh Sistem Tanam Terhadap Pertumbuhan dan Hasil Beberapa Varietas Padi Sawah di Subak Babakan KabupatenTabanan Bali. http://www.ntb.litbang.deptan.go.id /ind/ 2006/ TPH/. Diakses tanggal 17 Nopember 2018.

Benu, O. L., Suzana, Joachin N.K.D., dan Sudarti. 2011. Analisis Efisiensi Penggunaan FaktorFaktor Produksi pada Usahatani Padi Sawah di Desa Mopuyu Utara Kecamatan Dumoga Utara Kabupaten Bolaang Mongondow. Jurnal Agri-sosioekonomi Unsrat, ISSN 19074298. 7(1):38- 47. Diakses tanggal 20 November 2018.
Eldo Rian, Tinjung Mary Prihatanti dan Hendrik Yohanes Hadapdah, 2018. Faktor-Faktor yang Mempengaruhi Adopsi Petani Terhadap Penerapan Sistem Tanam Jajar Legowo di Desa Barukan Kecamatan Tenggara Kabupaten Semarang. http://ejurnal.fp.uns.ac.litbang.Pertania n.go.id/index. php/article/ download/ 179/ 769. Diakses tanggal 20 November 2019.

Mira Apriani, Dwi Rachmini dan Amzul Arifin, 2018. Pengaruh Tingkat Penerapan Tehnologi Pengelolaan Tanaman Terpadu Terhadap Efisiensi Teknis Usahatani Padi. Jurnal Agribisnis Indonesia vol 6 no. 2 Desember 2018 hal. 121-132. Diakses

Moh. Assad, BananiekS, Warda dan Abidin Z, 2017. Analisis Persepsi Petani Terhadap Penerapan Tanam Jajar Legowo Padi Sawah di Sulawesi Tenggara. http://ejurnal.litbang.pertanian.go.id/index. php/jpengkajian/article/view/6521.

Nania Agrina, Sinar Indra K. dan Muh. Jufri, 2018. Peran Kelompok Tani dalam meningkatkan Produktivitas Usahatani Padi Sawah.http://ejurnal.usu.ac.id/indeksphpcere ss/article/download/21345/9320. Diakses tanggal 22 November 2019.

Saerodji, 2013. Sistem Jajar Legowo Dapat Meningkatkan Produktivitas padi. BBPP Ketindan. Satria Putra Utama, Indra Cahya Dinata dan Rahmat Junaria, 2007. FaktorFaktor yang Berhubungan dengan Tingkat Adopsi Petani pada Tehnologi Budidaya Padih Sawah Sistem legowodi Kelurahan Dusun Besar Kecamatan Gadung Cermpaka Kota Bengkulu. https://media neliti.com. _Diakses tanggal 19 November 2019.

Soekartawi, 2006. Analisis Usahatani. Universitas Indonesia. Jakarta.

Suharyanto, Jakung H. Mulya, Dwiyono H. Darwanto dan Sri Widodo, 2015. Analisis Produksi dan Efisiensi Pengelolaan Tanaman Terpadu Padi Sawah di Provinsi Bali. Jurnal Penelitian Tanaman Pangan Vol. 34 No. 2 tahun 2015. Diakses tanggal 21 November 2019.

Tryono A, Purwanto dan Budiyanto, 2013. Efisiensi Penggunaan Pupuk N untuk Pengurangan Kehilangan Nitrat pada Lahan Pertanian. Prosiding Seminar Nasional Pengelolaan Sumberdaya Alam dan Lingkungan. ISBN 978602-17991-1-2:526-531. Diakses tanggal 11 Pebruari 2019.

Unadi, A dan Suparlan. 2011. Dukungan Teknologi Pertanian Untuk Industrialisasi Agribisnis Pedesaan. Makalah Seminar, Balai Besar Pengembangan Mekanisasi Pertanian Bogor. 